\title{
Severe Serotonin Depletion after Conditional Deletion of the Vesicular Monoamine Transporter 2 Gene in Serotonin Neurons: Neural and Behavioral Consequences
}

\author{
Nicolas Narboux-Nême ${ }^{1,2}$, Corinne Sagné3, Stephane Doly ${ }^{1,2}$, Silvina L Diaz ${ }^{1,2}$, Cédric BP Martin ${ }^{2,4}$, \\ Gaelle Angenard $^{1,2}$, Marie-Pascale Martres ${ }^{2,5,6}$, Bruno Giros ${ }^{2,5,6,7}$, Michel Hamon ${ }^{2,4}$, Laurence Lanfumey ${ }^{2,4}$, \\ Patricia Gaspar*,1,2 and Raymond Mongeau ${ }^{2,4}$ \\ 'INSERM, UMR-S 839, Institut du Fer à Moulin, Paris, France; ${ }^{2}$ Université Pierre and Marie Curie, Paris, France; ${ }^{3}$ CNRS UMR8 $192-$ Université \\ Paris Descartes, Paris, France; ${ }^{4}$ INSERM, U894, Paris, France; ${ }^{5}$ INSERM, U952, Paris, France; ${ }^{6}$ CNRS UMR7224, Paris, France; ${ }^{7}$ Department of \\ Psychiatry, Douglas Hospital, McGill University, Montreal, Canada
}

\begin{abstract}
The vesicular monoamine transporter type 2 gene (VMAT2) has a crucial role in the storage and synaptic release of all monoamines, including serotonin (5-HT). To evaluate the specific role of VMAT2 in 5-HT neurons, we produced a conditional ablation of VMAT2 under control of the serotonin transporter (slc6a4) promoter. VMAT2 ${ }^{\text {sert-cre }}$ mice showed a major (-95\%) depletion of 5-HT levels in the brain with no major alterations in other monoamines. Raphe neurons contained no 5-HT immunoreactivity in VMAT2 ${ }^{\text {sert-cre }}$ mice but developed normal innervations, as assessed by both tryptophan hydroxylase 2 and 5-HT transporter labeling. Increased 5-HTIA autoreceptor coupling to $\mathrm{G}$ protein, as assessed with agonist-stimulated $\left[{ }^{35} \mathrm{~S}\right] \mathrm{GTP}-\boldsymbol{\gamma}$-S binding, was observed in the raphe area, indicating an adaptive change to reduced 5-HT transmission. Behavioral evaluation in adult VMAT2 ${ }^{\text {sert-cre }}$ mice showed an increase in escape-like reactions in response to tail suspension and anxiolytic-like response in the novelty-suppressed feeding test. In an aversive ultrasoundinduced defense paradigm, VMAT2 ${ }^{\text {sert-cre }}$ mice displayed a major increase in escape-like behaviors. Wild-type-like defense phenotype could be rescued by replenishing intracellular 5-HT stores with chronic pargyline (a monoamine oxidase inhibitor) treatment. Pargyline also allowed some form of 5-HT release, although in reduced amounts, in synaptosomes from VMAT2 $2^{\text {sert-cre }}$ mouse brain. These findings are coherent with the notion that 5-HT has an important role in anxiety, and provide new insights into the role of endogenous 5-HT in defense behaviors.

Neuropsychopharmacology (20II) 36, 2538-2550; doi:I0.1038/npp.20I I.I42; published online 3 August 20I I
\end{abstract}

Keywords: conditional knockout mice; serotonin transporter; depression; anxiety; raphe; defense behaviors

\section{INTRODUCTION}

Serotonin (5-HT) has a central importance in the control of mood and anxiety states (Lucki, 1998). Dysfunctions of 5-HT neurotransmission can result from alterations at several critical points of monoamine metabolism such as synthesis, release, reuptake, catabolism, or serotonin receptors (Morilak and Frazer, 2004). All these constitute entry points to pharmacological therapeutic approaches (Berton and Nestler, 2006) and to genetic variations that impact disease predisposition. Vesicular monoamine transporters (VMATs) seem important targets with regard to the neurobiology of mood. Indeed, the initial formulation of the monoamine theory of depression was derived from studies with reserpine, an irreversible VMAT blocker, prescribed as

*Correspondence: Dr P Gaspar, INSERM UMR-S 839, Institut du Fer à Moulin, 17 Rue du Fer à Moulin, 75005, Paris, France, Tel: + 33। 458761 I I, Fax: + 331 458761 30, E-mail : patricia.gaspar@inserm.fr Received I6 May 201 I; revised 9 June 201 I; accepted I5 June 20 I I an antihypertensive agent, subsequently found to cause depression in humans (Freis, 1954). Moreover, there is evidence for a link of depression to genetic polymorphism of the VMAT2 gene (Christiansen et al, 2007; Gutierrez et al, 2007). The main function of VMAT is to concentrate biogenic amines into intracellular storage organelles such as synaptic vesicles, shielding them from degradation, and concentrating them for release into the synaptic cleft (Henry et al, 1998). Nevertheless, 5-HT can also function as a paracrine transmitter by acting on receptors distant from synaptic release sites (Bunin and Wightman, 1999), and non-vesicular release of neurotransmitters is known to occur under some physiological conditions (Attwell et al, 1993; Wu et al, 2007).

VMATs exist as two different isoforms: VMAT1 mainly expressed in chromaffin and enterochromaffin cells and VMAT2 essentially expressed in monoaminergic neurons (Erickson et al, 1996; Erickson and Eiden, 1993). Microdialysis (Adell and Artigas, 1998) and voltametry (Bunin et al, 1998; O'Connor and Kruk, 1991) experiments showed 
that tetrabenazine, a selective VMAT2 blocker, prevents the release of 5-HT in the raphe and in axon terminal fields, whereas VMAT2-KO mice showed no release of amines (Fon et al, 1997; Wang et al, 1997). VMAT2-KO mice do not survive beyond the first postnatal days (Alvarez et al, 2002; Fon et al, 1997; Wang et al, 1997) preventing the long-term evaluation of the consequences of a lack of monoamine/5HT release. VMAT2 heterozygous mice with rather small (20-30\%) reductions in brain amines showed no change in anxiety-like behaviors, but indications of a 'depression-like' phenotype (Fukui et al, 2007). However, it was unclear whether this phenotype was linked to a reduced release of 5-HT or of other amines (dopamine (DA), noradrenaline (NA), histamine) that also depend on VMAT2 for vesicular storage.

To overcome this limitation, we generated a conditional deletion of VMAT2 that allowed investigating the role of this transporter specifically in 5-HT neurons. Specific ablation of VMAT2 in raphe 5-HT neurons was obtained by Cre recombinase expressed under the control of the 5-HT transporter gene (SERT, slc6a4) promoter. We report that

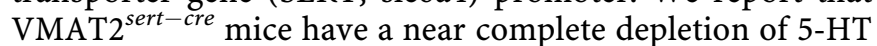
in the brain, consequent to abolished vesicular 5-HT uptake. Raphe neurons develop normally and show a normal innervation of target areas. A consequence of sustained 5-HT depletion was to increase the coupling of $5-\mathrm{HT}_{1 \mathrm{~A}}$ autoreceptors with its $\mathrm{G}$ protein, a known sensitive index of chronic changes in 5-HT levels. Behavioral observations in adults indicated that abolished synaptic 5-HT release caused anxiolytic-like phenotype, while increasing reactivity to innately aversive stimuli. The latter alteration was reversed by a 3-week treatment with pargyline, a monoamine oxidase inhibitor (MAOI), which markedly increased brain 5-HT levels. These observations are coherent with the notion that elevated levels of endogenous 5-HT in stressful situations can inhibit prepotent behaviors and is linked to anxiety (Gray and McNaughton, 2000). This study established VMAT2 $2^{\text {sert }-c r e}$ mice as a powerful model to analyze the role of $5-\mathrm{HT}$ in otherwise normally developed raphe neurons.

\section{MATERIALS AND METHODS}

\section{Animals}

Procedures involving animals and their care were conducted in accordance with the directives of the European Community (council directive 86/609) and the French Agriculture and Forestry Ministry (council directive 87-848, 19 October 1987, permissions $75-977$ to LL and 00782 to $P G)$.

The floxed VMAT2 mouse line was produced at the Mouse Clinical Institute (Institut Clinique de la Souris, MCI/ICS, Illkirch, France) in coordination with unit Inserm U952 (Bruno Giros, to whom correspondence regarding the mouse line should be addressed: bruno.giros@inserm.fr). A 9-kb fragment of the VMAT2 gene encompassing exons 1-3 was subcloned into the targeting vector and the two lox $\mathrm{P}$ sites and the neomycin-selectable cassette flanked by two FRT sites were introduced in introns flanking the first coding exon. Embryonic stem cells were electroporated with the targeting vector and cell clones resistant to selection were screened by PCR and Southern analysis to identify clones that resulted from a correct targeting event (2/744 clones analyzed). Excision of the neomycin cassette was performed in vivo by crossing chimeric mice with transgenic mice expressing the Flp recombinase under control of the early $\beta$-actin promoter. The presence of the floxed allele in the progeny was screened by PCR. $V M A T 2^{l o x / l o x}$ mice were maintained on a C57BL/6J background.

The SERT ${ }^{\text {cre }}$ mouse line has been described previously (Zhuang et al, 2005). This is a gene trap construction, which replaces exon 14 of the serotonin transporter gene (SERT) with a gene sequence encoding cre-recombinase. Previous studies have shown that recombination occurs by E12 in the raphe neurons (Narboux-Neme et al, 2008) and that virtually all tryptophan hydroxylase 2 (TPH2) neurons in the raphe have recombined in postnatal life (Zhuang et al, 2005). Male VMAT2 $2^{\text {lox } /+}:: S E R T^{\text {crel+ }}$ or VMAT2 $2^{\text {lox } / l o x}:: S E R T^{\text {crel+ }}$ mice were mated with female VMAT2 ${ }^{\text {lox/lox }}$ to generate the three genotypes that were analyzed: VMAT2 $2^{\text {lox/lox }}:: S E R T^{\text {crel+ }}$ (recombined), VMAT2 $2^{\text {lox/lox }}$ (control 1), and VMAT2 $2^{\text {lox/+ }}$ $:: S E R T^{\text {crel+ }}$ (control 2). After weaning and sexing, males and females were housed separately in groups of 6-8 animals per cage and maintained under standard laboratory conditions $\left(22 \pm 1{ }^{\circ} \mathrm{C}, 60 \%\right.$ relative humidity, $12-12 \mathrm{~h}$ lightdark cycle, food and water ad libitum). Male mice were used at 2-3 months of age when their body weight in each genotype equally ranged between 20 and $25 \mathrm{~g}$ (NarbouxNême et al, 2009). Some histological assays (VMAT and 5-HT immunohistochemistry) were performed on P7 mice for early detection of the phenotype, which was found the same at adult ages. In addition, some C57BL/6J mice (purchased from Janvier, France) were used for pharmacological studies.

\section{Neurotransmission Studies}

Tissue levels of 5-HT, 5-hydroxyindolacetic acid (5-HIAA), $\mathrm{NA}$, and DA were determined using high-pressure liquid chromatography with electrochemical detection (HPLC-ED) as described previously (Mongeau et al, 2010). Crude synaptosomes from VMAT2 $2^{\text {sert-cre }}$ and control mice, prepared as described previously (Gray and Whittaker, 1962), were used in experiments for measurements of $\left[{ }^{3} \mathrm{H}\right] 5-\mathrm{HT}$ uptake and release induced with the releasing agent 3,4-methylenedioxymethamphetamine (MDMA: $0.1 \mathrm{nM}-10 \mu \mathrm{M})$ or potassium (3-100 mM). Quantitative autoradiography of $5-\mathrm{HT}_{1 \mathrm{~A}}$ receptor-mediated $\left.{ }^{35} \mathrm{~S}\right] \mathrm{GTP}-\gamma$ $S$ binding using the non-selective agonist 5-carboxamidotryptamine (5-CT; $10-1000 \mathrm{nM}$; non-specific binding defined by WAY 100635) was performed as described previously (Fabre et al, 2000). See Supplementary online information for further details.

\section{Histological Analyses}

Mice were perfused transcardiacally with $4 \%$ paraformaldehyde, and their brains were postfixed overnight in $4 \%$ paraformaldehyde, cryoprotected in 30\% sucrose, and serially sectioned $(60-\mu \mathrm{m}$ thick sections) on a freezing microtome. Alternate series for immunohistochemistry, in situ hybridization, and counterstaining were used. 
Immunohistochemistry was performed using specific antibodies against VMAT2 (1:10 000, Phoenix), 5-HT (1:50 000, Sigma), and SERT (1:1000, Calbiochem) as described previously (Alvarez et al, 2002). Secondary antibodies used were biotinylated anti-rabbit IgG $(1: 300$, Jackson Laboratories) followed by avidin-biotin-peroxidase complex $(1: 400$, Amersham). Peroxidase activity was detected with $3,3^{\prime}$-diaminobenzidine peroxide. In situ hybridization experiments were performed as described previously (Bally-Cuif and Wassef, 1994). The TPH2 c-DNA plasmid described previously (Cote et al, 2003) was donated by P Ravassard (CRICM, UPMC, Paris).

Images were captured using a Cool Snap FX camera fitted to a Leica DM RD microscope under consistent light conditions using $20 \times / 0.70$ objectives. Images were copied to 8-bit RGB digital format and analyzed using ImageJ software. The density of SERT-immunoreactive fibers was estimated by counting the number of intersecting fibers with a grid composed of hemicycloids, as described previously (Gaspar et al, 1991). The density of TPH2-labeled neurons was estimated in two sections through the rostral portion of the dorsal raphe nucleus. All neurons contained in a grid of $250 \times 250 \mu \mathrm{m}^{2}$ were counted. The grid was placed over three different areas of the dorsal raphe, for each case.

\section{Behavioral Testing}

Experiments were carried out in adult (2-4 months) VMAT2 ${ }^{\text {sert-cre }}$ mice and controls from the same litters that included both VMAT2 $2^{\text {lox/lox }}$ and VMAT2 $2^{\text {lox/ } /+}$ SERT $^{\text {cre/t+ }}$ male mice.

Elevated plus maze. The maze was made of polyvinylchloride with two lit open arms $\left(27 \times 5 \mathrm{~cm}^{2}\right)$ and two opaque closed arms $\left(27 \times 5 \times 15 \mathrm{~cm}^{3}\right)$. The arms radiated from a central platform $\left(5 \times 5 \mathrm{~cm}^{2}\right)$ and the apparatus was $38.5 \mathrm{~cm}$ above the floor. To initiate the 5-min test session, the mouse was placed on the central platform, facing an open arm. The mouse was considered to be on the central platform whenever two paws were on it, and in one of the arms when all four paws were inside. Behavioral analysis was performed using a video recording using ODlog (Macropod Software) by an observer unaware of the genotype. Results are reported as the time spent and the number of entries in the open arms to assess anxiety-like behavior, and total number of entries into both open and closed arms to assess locomotor activity.

Spontaneous locomotor activity. Locomotor activity was measured using a computer-based photobeam apparatus (Actisystem II, Panlab, Barcelona, Spain). Actimeter box (area: $300 \times 150 \mathrm{~mm}^{2}$; height $180 \mathrm{~mm}$; with plexiglass wall and grid floor) detected mouse movements by means of two infrared light beams. Mice were placed in the testing room at least $2 \mathrm{~h}$ before the experiment.

Novelty-suppressed feeding. Animals were placed one per cage for at least 1 week, and their bedding was changed just before food deprivation. All mice were deprived of their regular food for $48 \mathrm{~h}$ and placed in the testing room for at least $1 \mathrm{~h}$ before the test. They were then placed into an unfamiliar arena (area: $400 \times 400 \mathrm{~mm}^{2}$; height $180 \mathrm{~mm}$; containing bedding) with a small plate containing food at the center of the field. Latency to feed was measured using a video recording, from the time the mouse is placed in the periphery of the arena until the animal began feeding. Latency to feed was also measured in the home cage, to assess whether changes in latency might be accounted for by alteration in the feeding drive rather than reaction to the anxiogenic environment. The delay was measured from the time the mouse was placed at the periphery of the cage containing the food in the center.

Food consumption. Animals were placed one per cage for 1 week before measuring daily food intake over 1 week. The pellets consumed were measured by weighing the amount of remaining food each day.

Tail suspension test. The apparatus consists of three suspension units divided by walls (ID-Tech-Bioseb, Chaville, France). Mice were suspended by the tail, using an adhesive tape attached to a strain gauge transducing movements into a signal transmitted to a central unit for signal digitalization. Although VMAT2 $2^{\text {sert-cre }}$ mouse weights differ from controls during postnatal life (NarbouxNême et al, 2009), weight differences were no longer observed at adult age which eliminates any bias in measurements with this test. The duration of immobility was measured automatically by the software over a 6 -min period. Struggling duration was analyzed from the traces generated by the software, and was defined as the total time the mouse spent in activity burst (ie, excluding all the small movements), during the 6-min test period. Activity burst was defined as a force exerted on the transducer $\geqslant 3 \mathrm{~g}$ above the baseline value for $>2 \mathrm{~s}$.

Ultrasound-induced defense reactions. Mice were tested for their innate fear reactions to a train of ultrasonic stimuli (US), as described previously (Mongeau et al, 2003). Animals were placed one per cage for at least 1 week before testing. In brief, $100 \mathrm{~ms}$ frequency sweeps between 17 and $20 \mathrm{kHz}, 85 \mathrm{~dB}$, alternately ON $2 \mathrm{~s}$ and then OFF $2 \mathrm{~s}$ for $1 \mathrm{~min}$ were delivered into the home cage $\left(18 \times 29 \mathrm{~cm}^{2}\right)$ after a 3 -min baseline period. Flight reactions triggered during ON periods were measured as the number of running events from one side of the cage to the other followed by behavioral arrest, whereas the percentage time freezing to the US was quantified by sampling events of complete immobility (except respiration) every $4 \mathrm{~s}$ during the OFF period. These defense behaviors were measured from a video file by an observer unaware of mouse genotype.

\section{Pargyline Treatment}

Mice were treated using subcutaneous osmotic minipumps (Alzet model 2004) to avoid injection handling which alters mice spontaneous defense behaviors to the US. Chronic pargyline treatment was carried out to achieve sustained MAOA and MAOB inhibition and optimally enhanced 5-HT neurotransmission in both control and VMAT2 ${ }^{\text {sert-cre }}$ mice. Pargyline $(70 \mathrm{mg} / \mathrm{kg} \times$ day; Fluka, Buchs, Switzerland) or vehicle (water) was administered for 3 weeks using 
minipumps inserted under sterile conditions on the back of animals under pentobarbital anesthesia $(55 \mathrm{mg} / \mathrm{kg}$, i.p.).

\section{Statistics}

Data were analyzed using Student's $t$-test when comparing two groups. The $\left[{ }^{35} \mathrm{~S}\right] \mathrm{GTP}-\gamma$-S binding data and the effects of pargyline treatment on 5-HT levels and flight behaviors in relation to the genotype were analyzed using two-way ANOVA, followed by Bonferonni's post hoc test. $\mathrm{EC}_{50}$ values were compared by one-way ANOVA, followed by Bonferonni's test. Statistical significance was set at $p<0.05$.

\section{RESULTS}

\section{Specific Invalidation of the VMAT2 Gene in 5-HT Neurons}

Conditional ablation of VMAT2 was obtained by inserting loxP sequences into the genomic sequence of the VMAT2 gene by homologous recombination, which produced the new mouse line VMAT2 $2^{l o x / l o x}$ (Figure 1). These mice were crossed to a previously described mouse line in which the 5-HT transporter (SERT, Slc6a4) promoter drives the expression of bacterial Cre recombinase (Narboux-Neme et al, 2008; Zhuang et al, 2005). The VMAT2 ${ }^{l o x / l o x}:: \mathrm{SERT}^{\text {cre/+ }}$ double transgenic line (hence termed 'VMAT2 $2^{\text {sert-cre }}$ ) was amplified for analysis. As with other 5-HT-depleted transgenic mice (Alenina et al, 2009; Trowbridge et al, 2010), there was an increased mortality of VMAT2 $2^{\text {sert-cre }}$ mice between P1 and P30 compared with control mice.

We first checked the effectiveness and selectivity of Cremediated excision using an antiserum that specifically stains the VMAT2 isoform. In wild-type (C57BL/6J) and VMAT2 $2^{l o x / l o x}$ mice, immunolabeling was observed in neurons of the raphe, the locus coeruleus, the substantia nigra, and the hypothalamus (Figure 2a). In VMAT2 ${ }^{\text {sert-cre }}$ mice (Figure 2a), VMAT2 immunostaining was abolished in raphe neurons but was still present in noradrenergic neurons of the locus coeruleus, in dopaminergic neurons of the substantia nigra. Similarly, VMAT2 immunostaining was unchanged in the hypothalamus and histamine neurons (Figure 2a). No visible reduction in VMAT2 immunostaining was detected in heterozygote mice lacking only one allele of the VMAT2 gene (VMAT2 ${ }^{\text {lox/+ }}:: \mathrm{SERT}^{\text {crel+t}}$; data not shown).

5-HT immunocytochemistry showed a major and uniform depletion of 5-HT immunostaining in all axon terminal fields (Figure $2 \mathrm{~b}$ ) with very faint residual staining in raphe neurons in the brainstem in P7 mice (Figure 2b) and a complete lack of labeling in the adult raphe. However, the density of TPH2-positive neurons, in the rostral part of the dorsal raphe nucleus, was unchanged (Figure 2c). To assess raphe projections, immunolabeling was performed with anti-SERT antibodies. Examination of serial coronal sections through the brain showed a comparable distribution and morphology of SERT-labeled axons in VMAT2 $2^{\text {sert-cre }}$ and control brains. The density of SERT-labeled axons was estimated in the cerebral cortex and hippocampus. This showed no difference in fiber density between control and mutants (Figure 2c). Overall, these results indicated that

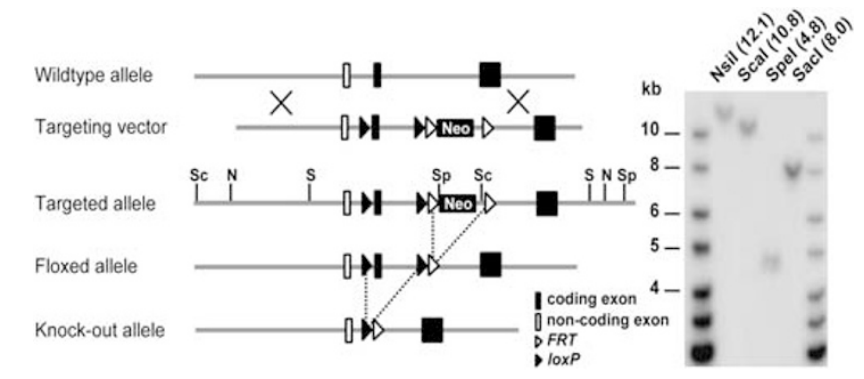

Figure I Conditional ablation of the VMAT2 gene. Schematic representation of the wild-type, targeted, and mutated VMAT2 alleles. Two loxP sites and a neomycin-selectable marker flanked by FRT sites were inserted by homologous recombination into the introns flanking the first VMAT2 coding exon. The correct targeting event in one positive ES cell clone was evaluated by Southern blotting with a probe directed against the neomycin sequence after hydrolysis with four different restriction enzymes. The location of the restriction sites is indicated on the targeted allele (N, Nsil; Sc, Scal; Sp, Spel; S, Sacl). Theoretical sizes of the fragments (in $\mathrm{kb}$ ) are indicated in brackets. The neomycin cassette was subsequently excised in vivo by Flp-mediated recombination to produce the floxed allele.

5-HT raphe neurons developed normally in VMAT2 ${ }^{\text {sert-cre }}$ mutants compared with WT mice.

\section{Consequences on Monoamines Metabolism, Uptake, and Signal Transduction}

Tissue monoamine levels were measured by HPLC in various brain areas (such as the cortex, striatum, hippocampus, brainstem), gut, and blood, as these tissues are known to produce or contain large amounts of 5-HT. Monoamines levels were not significantly different in wildtype (C57BL/6J), VMAT2 $2^{\text {lox/lox }}$, and VMAT2 $2^{\text {lox/+ }} / \mathrm{SERT}^{\text {cre/+ }}$ mice, which lack one allele of VMAT2 (results not shown); hence, in subsequent studies, $\mathrm{VMAT2}{ }^{l o x / l o x}$ and the VMAT2 $^{\text {lox/+ }} /$ SERT $^{\text {crel+ }}$ mice were pooled as controls. Dramatic decreases in 5-HT levels were observed throughout the brains of VMAT2 $2^{\text {sert-cre }}$ mice (from -92 to $-96 \%$ ), with no significant differences between brain structures (Figure 3a, left). Remarkably, no changes in 5-HIAA levels were observed (Figure 3a, right). This suggests (with data of Figure 2c) that 5-HT was produced in normal amounts. DA levels in the striatum and NA levels in the hippocampus and the cortex (Figure 3 ) were not or only marginally altered, although there was a $17 \pm 3 \%(p<0.01)$ decrease of hippocampal NA in VMAT2 ${ }^{\text {sert-cre }}$ mice (that could be explained by a lack of stimulatory action of 5-HT on NA terminals in that area (Mongeau et al, 1994)) as compared with controls (Figure 3b). By contrast, 5-HT levels were normal in the gut (Figure 3c), consistent with the fact that enterochromaffin cells express VMAT1 rather than VMAT2 (Erickson et al, 1996). A different situation occurred in the blood in which a $80 \pm 3 \%(p<0.001)$ decrease in 5 -HT levels was noted (Figure $3 \mathrm{c}$ ), consistent with the notion that platelets use VMAT2 rather than VMAT1 to store 5-HT (Holtje et al, 2003).

The release of endogenous 5-HT was examined in synaptosome preparations obtained from the whole brain. No potassium-induced release of 5-HT was observed in untreated synaptosomes from VMAT2 ${ }^{\text {sert-cre }}$ mice (Figure 4a). $\left[{ }^{3} \mathrm{H}\right] 5-\mathrm{HT}$ uptake and MDMA- and 

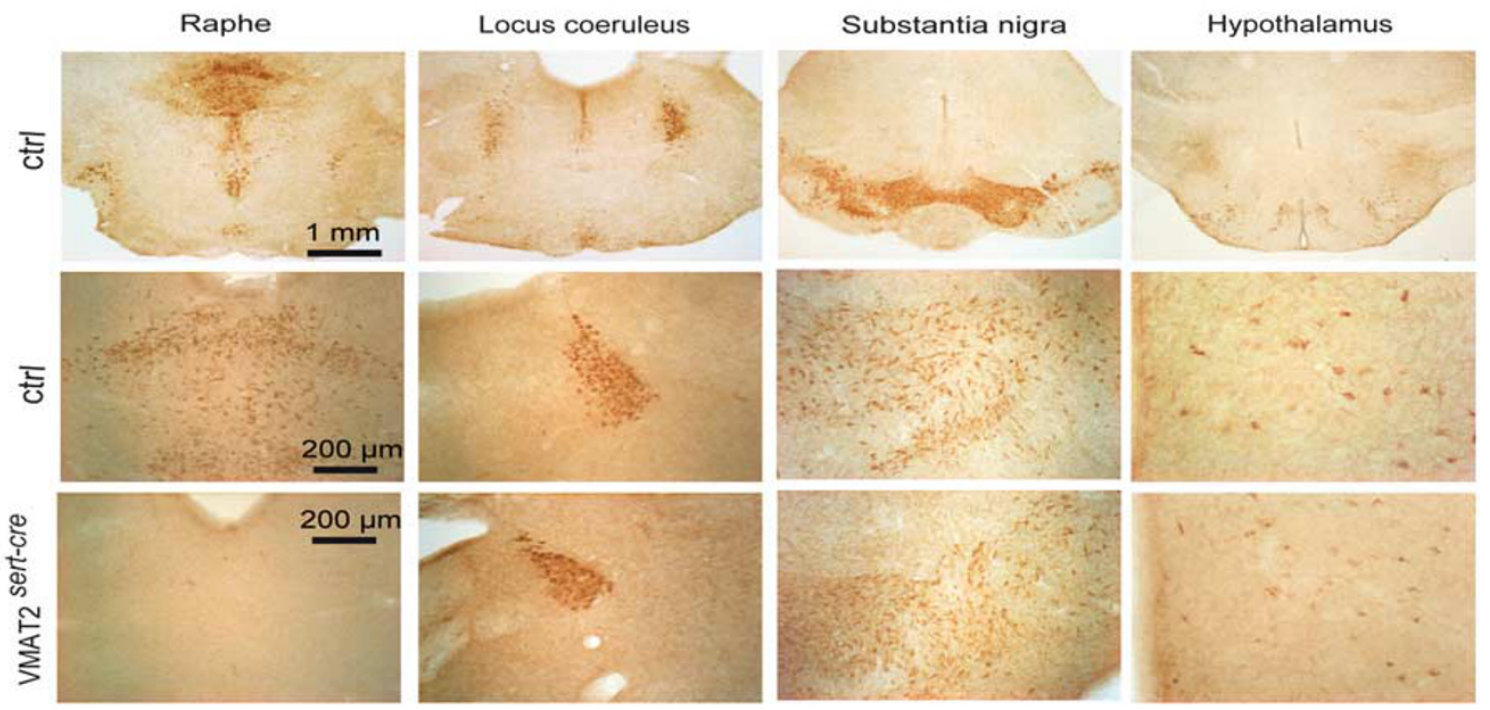

b
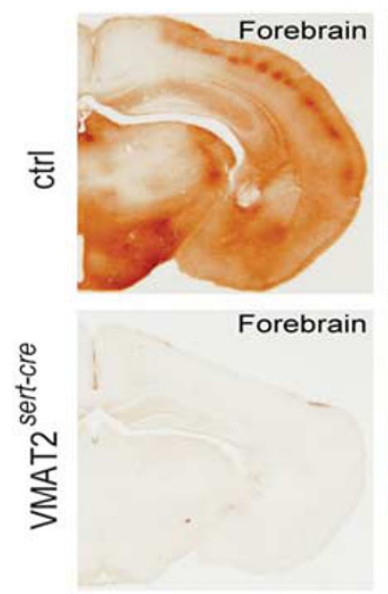
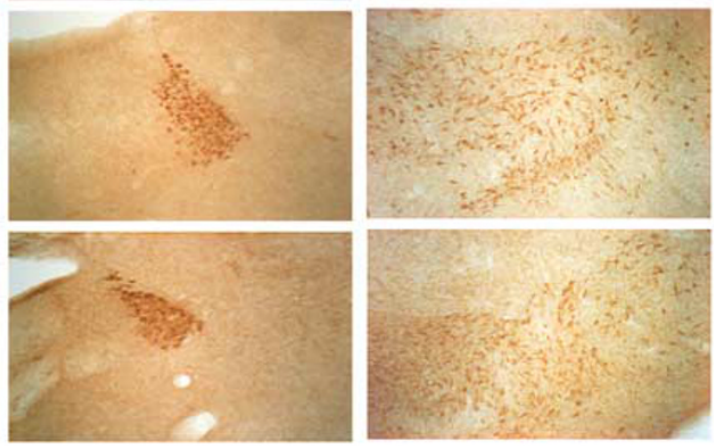

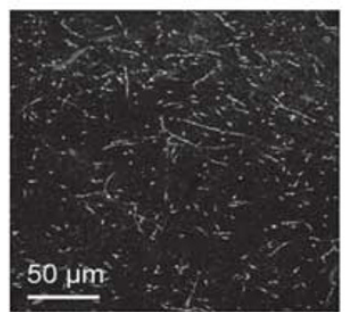

C

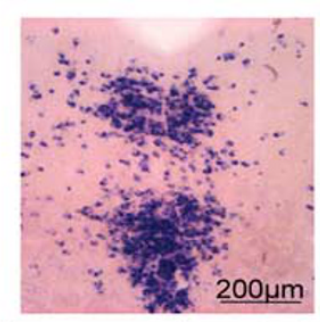

Raphe
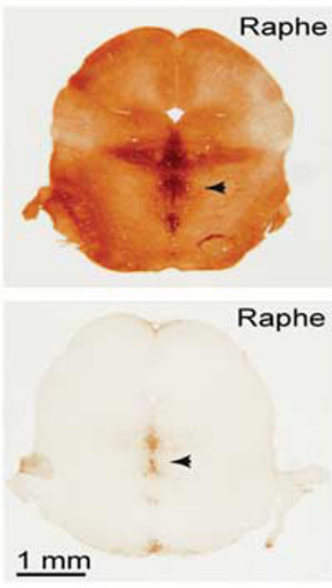

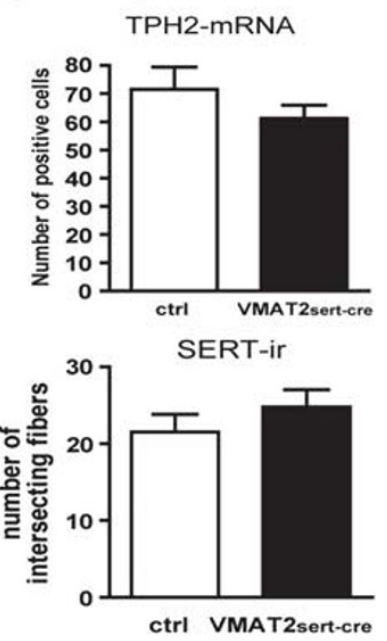

Figure 2 Distribution of VMAT2 and serotonergic markers in VMAT2 ${ }^{\text {sert-cre }}$ mice vs control mice. (a) VMAT2 immunostaining shows the major sites of VMAT2 expression in control and VMAT2 $2^{\text {sert-cre }}$ mice. Coronal sections at comparable levels in the raphe, the locus coeruleus, the substantia nigra, and the hypothalamus from P7 mice. VMAT2 immunostaining is abolished in the raphe neurons of VMAT2 ${ }^{\text {sert-cre }}$ mice compared with control mice, whereas immunostaining is unchanged in the noradrenergic, the dopaminergic, or the histaminergic neurons in the other brain areas. (b) A drastic depletion of 5-HT contents is visible with immunohistochemistry in both the raphe and the forebrain of VMAT2 ${ }^{\text {sert-cre }}$ mice compared with control mice. A faint 5-HT immunoreactivity remains visible in the raphe neurons (arrowhead) of VMAT2 ${ }^{\text {sert-cre }}$ mice. (c) Tryptophan hydroxylase 2 in situ hybridization shows the distribution of neurons in the dorsal raphe of VMAT2 $2^{\text {sert-cre }}$ mice, and the histogram shows the unchanged density of positive cells compared with controls (values are mean density on a surface of $784 \mu \mathrm{m}^{2}$, error bars $=\mathrm{SEM} ; n=5$ ). 5-HT transporter immunohistochemistry shows labeled axons with normal appearance in the hippocampus of VMAT2 $2^{\text {sert-cre }}$ mice and there was no significant change in the density of fibers in the stratum moleculare of the dentate gyrus compared with controls (values are mean intersecting fibers on a surface of $0.462 \mathrm{~mm}^{2}$, error bars $=S E M ; n=5-6$ ).

potassium-induced release were also analyzed on synaptosomes from control, SERT ${ }^{\text {crel+ }}$, and VMAT2 ${ }^{\text {sert-cre }}$ mice (Figure 4b-d). After loading, $\left[{ }^{3} \mathrm{H}\right] 5-\mathrm{HT}$ is normally distributed between two compartments, a fraction in the storage vesicles and another fraction in the axoplasm. The MAOI pargyline $(0.1 \mathrm{mM})$ was added to the medium to prevent degradation of $\left.{ }^{3} \mathrm{H}\right] 5-\mathrm{HT}$ occurring in the axoplasm.

In VMAT2 $2^{\text {sert-cre }}$ synaptosomes, uptake of $\left[{ }^{3} \mathrm{H}\right] 5-\mathrm{HT}$ was reduced to a similar level as that observed in reserpine $(0.1 \mu \mathrm{M})$-treated synaptosomes from WT mice (Figure $4 \mathrm{~b})$. In contrast, no significant alterations were noted in SERT ${ }^{\text {cre/+ }}$ synaptosomes. MDMA-induced release, occurring through the reversal of the reuptake carrier (Hekmatpanah and Peroutka, 1990; McKenna et al, 1991; Renoir et al, 2008), was analyzed in synaptosomes from WT and VMAT2 ${ }^{\text {sert-cre }}$ mice (Figure 4c). The total amount of $\left[{ }^{3} \mathrm{H}\right]-5-\mathrm{HT}$ in synaptosomes was decreased in VMAT2 $2^{\text {sert-cre }}$ or WT mice treated with reserpine compared with controls $\left(\mathrm{WT}=0.13 \pm 0.01 ; \mathrm{SERT}^{\text {cre/+ }}=0.14 \pm 0.02 ; \quad \mathrm{VMAT}^{\text {sert }- \text { cre }}=\right.$ $0.07 \pm 0.01 ; \quad W T+$ reserpine $=0.06 \pm 0.01 \mathrm{mmol} / \mathrm{g}$ of protein), as expected from the reduced uptake of $\left[{ }^{3} \mathrm{H}\right] 5-\mathrm{HT}$ into the storage vesicles of VMAT2 $2^{\text {sert-cre }}$ mice compared with WT mice (Figure 4b). There was a small but 
a

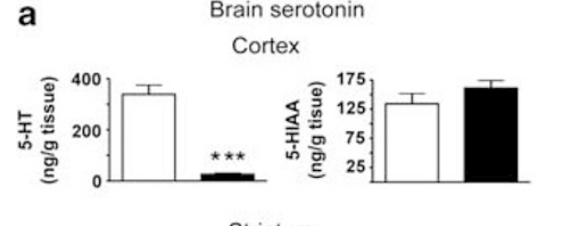

b

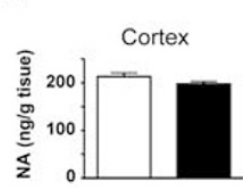

Brain catecholamines
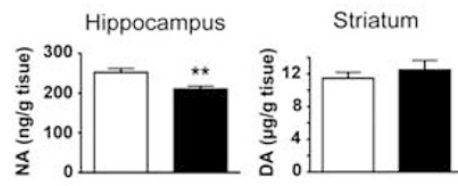

C

Serotonin in the periphery

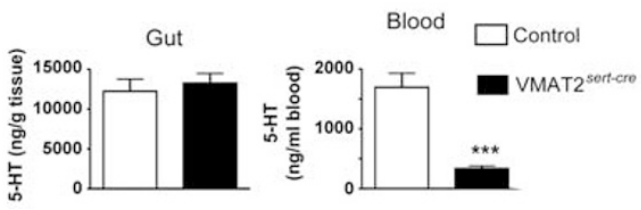

Figure 3 Tissue levels of monoamines in the brain and the periphery. (a) Tissue levels of 5-HT and 5-HIAA were determined in various dissected brain areas from adult control (open bars) and VMAT2 ${ }^{\text {sert-cre }}$ mice (black bars). There was a highly significant decrease in 5-HT levels in all examined brain areas. **** $p<0.000$ I; Student's $t$-test; error bars $=$ SEM; $n=5-6$. (b) Tissue levels of NA in the cortex and the hippocampus and DA in the striatum. There was no change in NA in the cortex but a small reduction in the hippocampus, whereas striatal DA levels were found unchanged using the Student's t-test; $n=5-6$, *** $<<0.01$. (c) Levels of $5-\mathrm{HT}$ in the gut and in the blood. There were no changes in the gut, whereas 5 -HT was significantly decreased in the blood ***** $p<0.000$ I; Student's t-test; $n=5-8$.

significant change in the concentration of MDMA that triggers $50 \%$ release in VMAT2 ${ }^{\text {sert }- \text { cre }}$ mice compared with control mice (Figure 4c): the dose-response curve was slightly shifted to the left when using VMAT2 $2^{\text {sert }- \text { cre }}$ synaptosomes $\quad\left(-\log \mathrm{EC}_{50}\right.$ : $\mathrm{VMAT}^{\text {sert }}$ cre $=7.35 \pm 0.11$; $\mathrm{WT}=6.86 \pm 0.09, n=3, p<0.01)$. A similar change compared with WT synaptosomes was found in WT synaptosomes treated with reserpine $\left(-\log \mathrm{EC}_{50}: \mathrm{WT}+\right.$ reserpine $=7.26 \pm 0.11, p<0.05)$, but not in synaptosomes from SERT ${ }^{+/ \text {cre }}$ mice $\left(-\log \mathrm{EC}_{50}: 6.69 \pm 0.14\right.$; Figure $\left.4 \mathrm{c}\right)$. However, the concentration of $\mathrm{KCl}$ necessary to trigger $50 \%$ of maximal release of $\left[{ }^{3} \mathrm{H}\right] 5-\mathrm{HT}$ was similar across all synaptosomes preparations (Figure $4 \mathrm{~d}$; $\mathrm{EC}_{50}$ : $\mathrm{WT}=24.7 \pm 8.5 \mathrm{mM} ; \quad \mathrm{VMAT}^{\text {sert }- \text { cre }}=21.8 \pm 5.4 \mathrm{mM}$; SERT $^{\text {cre/ }+}=23.9 \pm 4.8 \mathrm{mM}$; WT + reserpine $=25.9 \pm 8.5 \mathrm{mM}$ ). This release is likely to represent a predominantly axoplasmic pool of $\left[{ }^{3} \mathrm{H}\right] 5-\mathrm{HT}$ as all experiments were conducted in the presence of pargyline.

Potassium-induced release is only weakly dependent on the presence of calcium in the media under the abovedescribed conditions (varying from 0 to $30 \%$ at $3-100 \mathrm{mM}$ of $\mathrm{KCl}$; not shown), suggestive of non-vesicular release. Other experimental conditions were used to test calciumdependent release. This involved the retrieval of pargyline from the media and shorter potassium pulses $(30 \mathrm{~s})$. Under these conditions, we observed a calcium-dependent release of $\left[{ }^{3} \mathrm{H}\right] 5-\mathrm{HT}$ (indicated in Figure $4 \mathrm{e}$ as a decrease in the amount of radioactivity in synaptosomes after $\mathrm{KCl}$ stimulation) in WT mice, whereas no significant calciumdependent vesicular release was found in synaptosomes from VMAT2 ${ }^{\text {sert-cre }}$ mice.

To assess whether adaptive changes occur at 5-HT receptors as a consequence of VMAT2 ${ }^{\text {sert-cre }} 5$-HT depletion, we measured 5- $\mathrm{HT}_{1 \mathrm{~A}}$ receptor-stimulated $\left[{ }^{35} \mathrm{~S}\right] \mathrm{GTP}-\gamma-\mathrm{S}$ binding using 5-CT as the agonist (Fabre et al, 2000). $\left[{ }^{35}\right.$ S $]$ GTP- $\gamma$-S binding was significantly increased in the dorsal raphe nucleus in response to $5-\mathrm{HT}_{1 \mathrm{~A}}$ receptor activation by 5 -CT in VMAT2 $2^{\text {sert-cre }}$ compared with control mice $(p<0.0001$, two-way ANOVA, Figure 5a), suggesting an upregulation of $5-\mathrm{HT}_{1 \mathrm{~A}}$ autoreceptors and/or enhanced coupling efficacy of these autoreceptors to $G$ proteins. In contrast, no change in 5-CT-induced $\left[{ }^{35} \mathrm{~S}\right] \mathrm{GTP}-\gamma$-S binding was found in post-synaptic sites, such as the dorsal hippocampus (Figure 5b), the ventral hippocampus, and the septum (not shown).

\section{Behavioral Consequences}

We measured the consequences of VMAT2 $2^{\text {sert-cre }}$-induced 5-HT depletion in standard models of anxiety and depression. In the elevated plus maze (EPM), VMAT2 ${ }^{\text {sert-cre }}$ mice spent the same amount of time exploring the open arms as did control mice (Figure 6a). However, there was a significant decrease $(-37 \pm 7 \% ; p<0.05)$ in the overall entries into both the closed and the open arms (Figure 6a) suggesting a change in locomotor activity that could confound the interpretation of the EPM data. Indeed, specific assessment of locomotion with an actimeter also showed a $40 \%$ reduction in spontaneous locomotor activity of VMAT2 ${ }^{\text {sert-cre }}$ mice (Figure $6 \mathrm{~b}$ ).

To further explore the anxiety-related phenotype in a model less dependent on locomotion, we applied the novelty-suppressed feeding (NSF) test, in which there is a conflict between the feeding drive and risk assessment behaviors. VMAT2 ${ }^{\text {sert-cre }}$ mice initiated to feed much sooner (about three times faster; Figure 6c) than did control mice in the unfamiliar cage but not in the home cage, indicating an anxiolytic-like phenotype, rather than a change in appetite. Furthermore, in isolated adult mice of the same weight $(22 \pm 1 \mathrm{~g})$, food consumption measured during 1 week did not differ between transgenic and control mice (VMAT2 ${ }^{\text {sert }- \text { cre }}$ : $3.58 \pm 0.28 \mathrm{~g}$; control: $3.65 \pm 0.30 \mathrm{~g}$; mean \pm SEM. $n=5-6)$. Finally, when tested in the tail suspension test $(\mathrm{TST}), \mathrm{VMAT2}{ }^{\text {sert-cre }}$ mice were more reactive than were control mice. Indeed, immobility time was reduced (Figure $6 \mathrm{~d} ;-37 \pm 12 \% ; p<0.01$ ) and time spent actively struggling to escape was increased $(+68 \pm 13 \%, p=0.001)$. These observations suggested an increase in active defense behaviors of VMAT2 $2^{\text {sert-cre }}$ mice in the TST. 
a
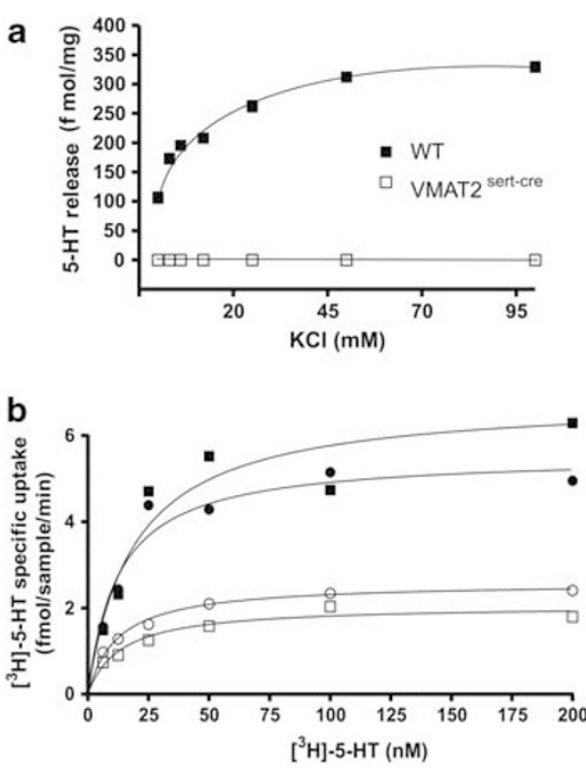

c

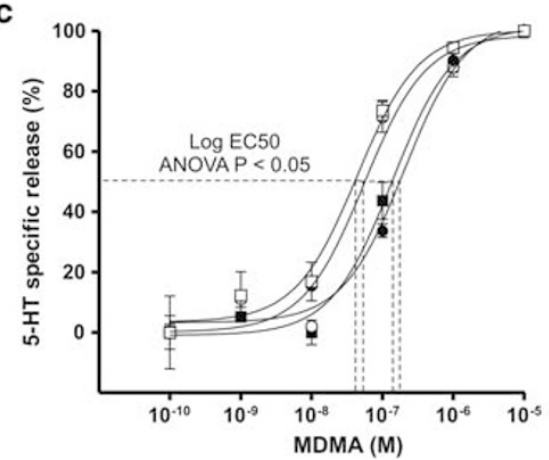

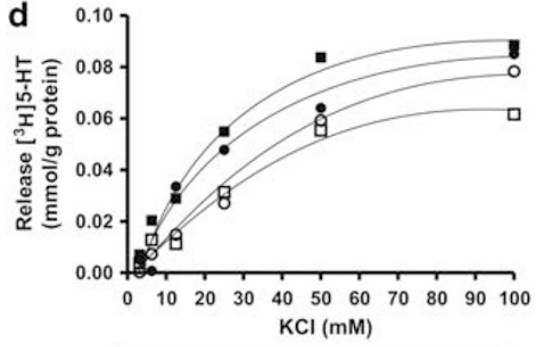

- WT a VMAT2 $2^{\text {sert-cre }}$

- SERT ${ }^{+/ c r e} \circ \mathrm{WT}$ reserpine
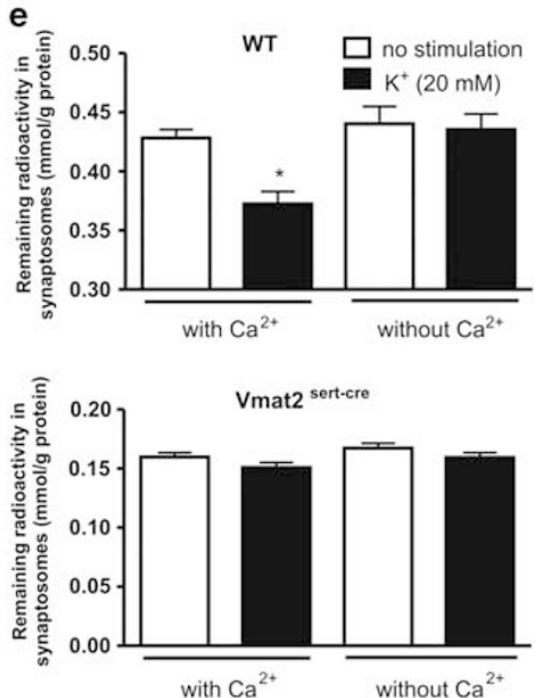

Figure 4 Uptake and release of $\left[{ }^{3} \mathrm{H}\right]-5-\mathrm{HT}$ using synaptosome preparations obtained from whole brain in controls, SERT ${ }^{\text {cre/+ }}$, and VMAT2 $2^{\text {sert-cre }}$ mice. (a) The release of endogenous 5-HT evoked with varying concentrations of potassium in synaptosomes from WT mice was not observed in synaptosomes from VMAT2 ${ }^{\text {sert-cre }}$ mice $(n=3)$. (b) $\left[{ }^{3} \mathrm{H}\right] 5-\mathrm{HT}$ uptake in VMAT2 ${ }^{\text {sert-cre }}$ or reserpine-treated $(0.1 \mu M)$ synaptosomes compared with WT or SERT ${ }^{\text {cre/ }}$

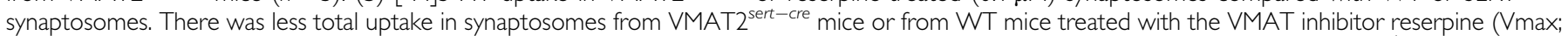
$V_{M A T 2}{ }^{\text {sert-cre }}=2.0 \pm 0.1 \mathrm{fmol} / \mathrm{min}$, reserpine $=2.6 \pm 0.07$, mean $\left.\pm \mathrm{SEM}, n=3\right)$ compared with synaptosomes from WT or SERT ${ }^{\text {cre } /+}$ mice $(V m a x:$ control $=6.8 \pm 0.5 \mathrm{fmol} / \mathrm{min}$; SERT ${ }^{\text {cre/ }+}=5.5 \pm 0.3, n=3$ ). There were no significant changes (using one-way ANOVA) in the Km values between groups $\left(W T=18.8 \pm 4.5 \mathrm{nM}\right.$; VMAT2 $2^{\text {sert-cre }}=13.5 \pm 3.2 \mathrm{nM}$; SERT ${ }^{\text {cre/ }+}=12.7 \pm 3 \mathrm{nM}$; reserpine $=12.25 \pm 1.4 \mathrm{nM}$; means \pm SEM, $n=3$ ). (c) The concentration response curve of the MDMA-induced $\left[{ }^{3} \mathrm{H}\right] 5-\mathrm{HT}$ release was slightly shifted to the left in preloaded synaptosomes from VMAT2 ${ }^{\text {sert-cre }}$ mice or reserpinetreated synaptosomes. (d) There were no major changes in potassium-induced $\left[{ }^{3} \mathrm{H}\right] 5-\mathrm{HT}$ release between various synaptosome preparations in conditions weakly dependent on calcium, $n=3$. (e) Under conditions in which potassium-induced release is fully dependent on the presence of calcium in the incubation buffer (brief stimulation in the absence of pargyline, WT synaptosomes top panel) there was no significant release in preloaded synaptosomes from VMAT2 $2^{\text {sert-cre }}$ mice (bottom panel).

Interestingly, $\mathrm{VMAT} 2^{\text {sert-cre }}$ mice also displayed a large increase in behavioral reactivity in response to stimulation with the innately aversive US $(p<0.01$; Figure $7 \mathrm{a})$. In addition, VMAT2 $2^{\text {sert-cre }}$ mice froze less in reaction to the US than did control mice (control: $69 \pm 7 \%$ of time during the OFF periods; VMAT2 ${ }^{\text {sert-cre }}$ : $37 \pm 8 \%$; mean \pm SEM.; $p<0.05, n=4-5$, not shown).

To examine whether the change in behavioral reactivity to the US in VMAT2 ${ }^{\text {sert-cre }}$ mice was due to reduced 5-HT levels, we investigated the effects of a long-term pargyline treatment $(70 \mathrm{mg} / \mathrm{kg} \times$ day, for 3 weeks). Pargyline reversed the 5-HT depletion $(-94 \pm 0.01 \%)$ observed in $\mathrm{VMAT}^{\text {sert-cre }}$ mice, and even markedly increased 5-HT levels compared with vehicle-treated control mice (Figure 7d). Nevertheless, after pargyline treatment, 5-HT tissue levels were still $20 \pm 13 \%$ lower in VMAT2 ${ }^{\text {sert-cre }}$ mutants than in pargyline-treated control mice (Figure 7d). Two-way ANOVA indicated a significant effect $(p<0.0001)$ of treatment $\mathrm{F}(1,19)=574$ and of genotype $\mathrm{F}(1,19)=46$, but no significant interactions $(F(1,19)=0.3)$. Pargyline also restored some 5-HT immunostaining in raphe neurons and axon terminals of VMAT2 $2^{\text {sert-cre }}$ mice (Figures $7 \mathrm{~b}$ and c), although the levels were lower than those observed in controls (not shown). In response to the US, VMAT2 $2^{\text {sert-cre }}$ mice treated with pargyline no longer displayed their increment of flight responses compared with control mice (Figure 7a). Two-way ANOVA indicated significant effects $(p=0.01)$ of treatment $\mathrm{F}(1,12)=9$, genotype $\mathrm{F}(1,12)=9$, and a significant treatment $\times$ genotype interaction $\mathrm{F}(1,12)=$ 10. Furthermore, there were no changes in the percentage of 
time spent freezing in response to the US in pargylinetreated mice (control: $87 \pm 6 \%$ of time during the OFF periods; VMAT2 ${ }^{\text {sert-cre }}: 76 \pm 24 \%$, not shown).

\section{DISCUSSION}

Previous studies have shown that the majority of brain monoamines resides in the vesicular storage pools and that pharmacological inhibition of VMAT prevents vesicular release of 5-HT (Adell and Artigas, 1998; Bunin et al, 1998; O'Connor and Kruk, 1991). We confirm here that VMAT2 is
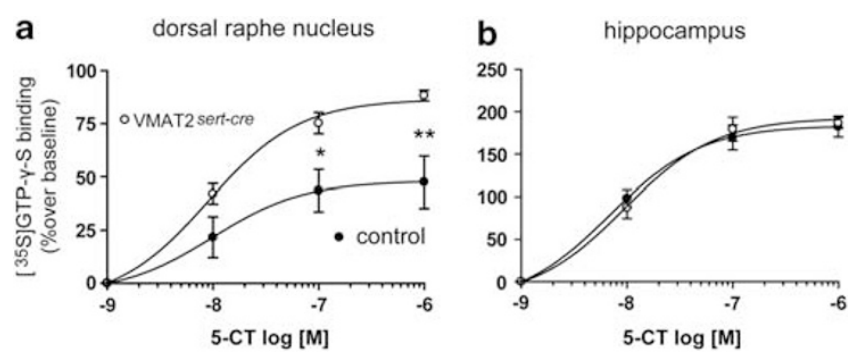

Figure $\left.5{ }^{35} \mathrm{~S}\right] \mathrm{GTP}-\gamma-\mathrm{S}$ binding in the dorsal raphe nucleus and the hippocampus after stimulation with the 5-HT IA agonist 5-carboxamidotryptamine (5-CT). (a) There was an increased coupling efficiency as shown by more agonist-induced $\left[{ }^{35} \mathrm{~S}\right] \mathrm{GTP}-\boldsymbol{\gamma}-\mathrm{S}$ binding in the raphe of VMAT2 $2^{\text {sert-cre }}$ mice (open circles) vs control mice (filled circles). Twoway ANOVA indicated a significant $(p<0.00 \mathrm{I})$ main effect of the genotype $(F(I, 35)=19)$, of $5-C T$ concentration $(F(3,35)=34)$, and a marginally significant $(P=0.06)$ genotype $\times 5-C T$ interaction $(F(3,35)=2.8)$. Post-hoc Bonferroni's tests indicated significant differences at specific concentrations ${ }^{*} p<0.05$, *** $p<0.01$. (b) There were no changes in the hippocampus. Error bars $=\mathrm{SEM}, n=6$. the only vesicular transporter implicated in this effect in the $\mathrm{CNS}$, as its genetic ablation in 5-HT neurons entirely reproduced the effects on 5-HT uptake of complete VMAT inhibition with reserpine. Interestingly, however, in VMAT2 $2^{\text {sert-cre }}$ mice, 5 -HT is probably produced at normal rates, as suggested by (1) the normal levels of TPH2 gene expression, (2) the normal amounts of 5-HIAA (the product of oxidative deamination of 5-HT), and (3) the normal increase in 5-HT levels after MAO inhibition by pargyline. Hence, all 5-HT produced or taken up by neurons, which cannot be stored into vesicles are rapidly metabolized by mitochondrial monoamine oxidases present in raphe neurons (Shih et al, 1997; Vitalis et al, 2002). As 5-HT continues to be produced in raphe neurons at a seemingly normal rate, it can still be released. Although such release is likely to be marginal under standard conditions because of the low endogenous levels of 5-HT, it could still occur after administration of a MAOI which causes a major increase in 5-HT tissue levels. Furthermore, it cannot be excluded that pargyline could enhance some form of vesicular storage (Buu, 1989). In both VMAT2 KO and VMAT2 $2^{\text {sert-cre }}$ mice, MAOIs restored some functions such as the inhibitory action of 5-HT on active defense reactions (Figure 7b) and normal growth (Alvarez et al, 2002; Narboux-Nême et al, 2009). This functional restoration in vivo fits well with the potassium- and MDMA-induced releases of $\left[{ }^{3} \mathrm{H}\right] 5-\mathrm{HT}$ observed in vitro in VMAT2 $2^{\text {sert-cre }}$ synaptosomes.

The mechanism involved in the $\left[{ }^{3} \mathrm{H}\right] 5-\mathrm{HT}$ release in VMAT2 $2^{\text {sert-cre }}$ synaptosomes is presently unclear, but three non-mutually exclusive possibilities can be discussed: (1) Release of $\left[{ }^{3} \mathrm{H}\right] 5-\mathrm{HT}$ through the carrier (Evans and Collard, 1988). Although this was suggested to occur in VMAT2 KO mice (Fon et al, 1997), we do not presently have any data in a

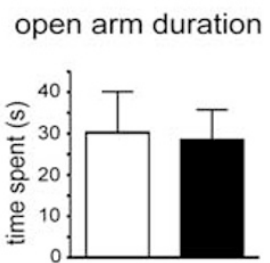

C

Novelty suppressed feeding test home cage

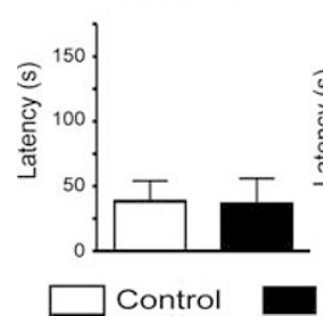

unfamiliar cage

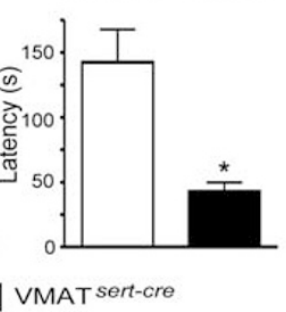

Elevated plus maze

open arm entries

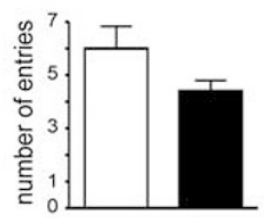

d

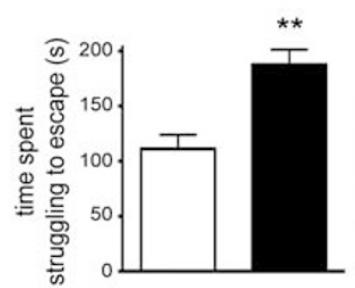

b

closed+open arms entries

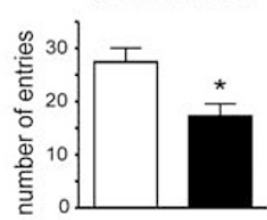



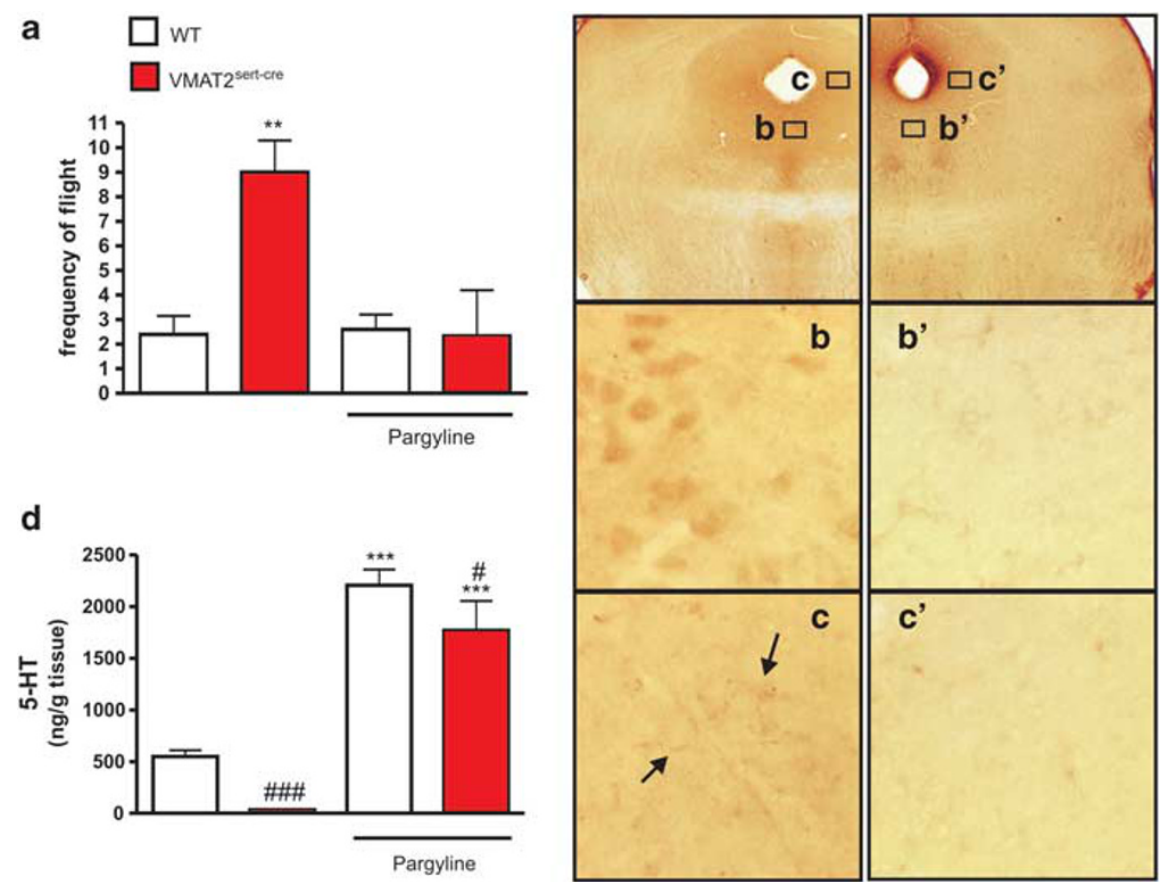

Figure 7 Inverse relationship between brain tissue levels of 5-HT and aversive ultrasound-induced flight behaviors in VMAT2 ${ }^{\text {sert-cre }}$ mice. (a) There was an enhancement of flight behaviors in reaction to the aversive ultrasound ( I min fast sweep $17-20 \mathrm{kHz}, 85 \mathrm{~dB}$ ) in VMAT2 $2^{\text {sert-cre }}$ mice compared with control mice, which was reversed by a chronic treatment with pargyline $(70 \mathrm{mg} / \mathrm{kg} \times$ day for 3 weeks $)$. $* * * 0.0$ I using Bonferonni's test. Error bars $=S E M, n=3-5$. $\left(b-c^{\prime}\right) 5-H T$-immunoreactive neurons were observed in the raphe area (panel b) and positive fibers were observed in dorsolateral periaqueductal gray areas in sections from VMAT2 $2^{\text {sert-cre }}$ mice treated with pargyline (c). This staining was absent in VMAT2 ${ }^{\text {sert-cre }}$ mice treated with saline ( $b^{\prime}$ and $\left.c^{\prime}\right)$. (d) Chronic pargyline reversed the severe 5-HT depletion occurring in VMAT2 ${ }^{\text {sert-cre }}$ mice, and markedly increased 5-HT levels (in the hippocampus). Bonferonni's test indicated a significant decrease in 5-HT levels in VMAT2 ${ }^{\text {sert-cre }}$ mutants compared with control mice (\#\# $p<0.00 \mathrm{I}$, \# $\left.p<0.05\right)$, and significant increases of 5HT levels after pargyline $(* * * p<0.00$ I) compared with control mice.

favor of flux reversal in VMAT2 ${ }^{\text {sert-cre }}$ mice. (2) Alternate vesicular storage and release pathways. It is known that 5-HT can passively cross the membrane of intracellular acidic organelles where it is protonated and remains trapped because charged monoamines cannot cross back membranes. In view of $\mathrm{pH}$ differences between vesicles and axoplasm, there could be at least a 100 -fold increase in $\left[{ }^{3} \mathrm{H}\right] 5-\mathrm{HT}$ vesicular concentration compared with the axoplasm (Njus et al, 1986), although this passively generated gradient remains very small compared with that generated by VMAT2, it may nevertheless be a way to compensate for VMAT2 loss. (3) Finally, there is evidence for uptake of 5-HT in catecholaminergic neurons (Cases et al, 1998; Zhou et al, 2005). Storage of $\left[{ }^{3} \mathrm{H}\right] 5-\mathrm{HT}$ in any non-serotonergic neurons, still normally expressing VMAT2 in VMAT2 ${ }^{\text {sert-cre }}$ mice, could account for some of the $\left[{ }^{3} \mathrm{H}\right] 5$ HT release observed here. Future studies are clearly required to understand how 5-HT release can occur in VMAT2 $2^{\text {sert-cre }}$ mice.

Beyond the cellular mechanisms involved, an important finding here is that $\left[{ }^{3} \mathrm{H}\right] 5-\mathrm{HT}$ stabilized through MAO inhibition in the axoplasm can be mobilized out of the synaptosomes. The small but significant changes in $\mathrm{EC}_{50}$ values obtained after MDMA stimulation indicate that the process underlying 5 - $\mathrm{HT}$ release in VMAT2 ${ }^{\text {sert-cre }}$ mice is likely to be different from that of WT mice. However, the relatively low calcium dependency of our release conditions in the presence of pargyline might preclude similar observation after potassium stimulation. It is also important to emphasize that in the absence of pargyline, calciumdependent vesicular release of 5-HT was not observed in $\mathrm{VMAT}^{\text {sert-cre }}$ mice.

Reduced 5-HT levels in VMAT2 ${ }^{\text {sert-cre }}$ mice caused a sensitization of the $5-\mathrm{HT}_{1 \mathrm{~A}}$ autoreceptors coupled to $\mathrm{G} \alpha \mathrm{i}$ proteins in the dorsal raphe nucleus. In contrast, the decrease in 5-HT contents in VMAT2 $2^{\text {sert-cre }}$ mice caused no adaptive changes of $5-\mathrm{HT}_{1 \mathrm{~A}}$ receptors in target areas, such as the hippocampus. This is in line with the notion that raphe $5-\mathrm{HT}_{1 \mathrm{~A}}$ autoreceptors, but not hippocampal $5-\mathrm{HT}_{1 \mathrm{~A}}$ receptors, show modulation in response to changes in $5-\mathrm{HT}$ levels (Fabre et al, 2000; Mannoury La Cour et al, 2006; Mongeau et al, 1997) and indicate that extracellular 5-HT level was much reduced at the level of serotonergic somas.

The VMAT2 $2^{\text {sert-cre }}$ mouse line offers an interesting model of hyposerotonergia, complementary to other recently described genetic mouse models (Trowbridge et al, 2010). All recent genetic hyposerotonergic models focused on reducing 5 -HT production either by targeting the central 5-HT synthesis enzyme, TPH2 (Alenina et al, 2009; Beaulieu et al, 2008; Gutknecht et al, 2008; Savelieva et al, 2008) or by invalidating the transcription factors controlling differentiation of raphe neurons such as pet 1 and $\operatorname{lm} x 1 B$ (Dai et al, 2008; Hendricks et al, 2003; Kiyasova et al, 2011; Zhao et al, 2006). The more severe 5-HT depletion observed here ( $-95 \%)$, compared with previous models ( -70 to $90 \%)$, is likely due to the fact that increased 5-HT degradation, when VMAT2 is absent, affects all sources of 5-HT (eg, produced by TPH1/TPH2). The present observations, consistent with 
Tph2 knockout mice (Alenina et al, 2009; Gutknecht et al, 2008), showed both a normal development of the raphe neurons, and a normal density of 5-HT terminals in the hippocampus and the cerebral cortex of VMAT2 $2^{\text {sert-cre }}$ mice. Subtle developmental defects may nonetheless exist given the large body of evidence supporting the role of 5 -HT in the maturation of neural circuits (Trowbridge et al, 2010).

Normal morphology of 5-HT neurons and brain specificity provides two major advantages of genetic models in general compared with pharmacological depletion methods such as, respectively, lesions of 5-HT neurons with 5,7-dihydroxytryptamine and depletion with p-chlorophenylalanine (PCPA). Compared with the Tph2 knockout which irreversibly inactivates 5 -HT synthesis, the VMAT2 ${ }^{\text {sert-cre }}$ mutation has also the advantage of rapid reversibility through MAO inhibition as TPH2 is not targeted or downregulated. Overall, VMAT2 selective deletion should allow more direct explorations of the function of monoamine release in otherwise normally developed raphe neurons.

Behavioral characterization of VMAT2 $2^{\text {sert-cre }}$ mice showed that depletion of central 5-HT stores reduces anxiety. This finding is in agreement with reports in several genetic models of 5-HT-deficient mice (Dai et al, 2008; Kiyasova et al, 2011) and with numerous studies using pharmacological approaches to decrease brain 5-HT in rats (Graeff, 2004; Griebel, 1995). Furthermore, decreased 5-HT input at several receptors (including the $5-\mathrm{HT}_{2 \mathrm{~A}}$ and $5-\mathrm{HT}_{2 \mathrm{C}}$ subtypes) clearly reduces anxiety in mice (Heisler et al, 2007; Mongeau et al, 2010; Weisstaub et al, 2006).

$\mathrm{VMAT}^{\text {sert-cre }}$ mice were first tested in the most standard model, the EPM, having a strong validity for anxiolysis mediated by the GABAergic system, but not so much, it seems from previous studies (McCreary et al, 1996), for the serotonergic system. Indeed, the effect of altering 5-HT on behaviors observed in the EPM was argued to be the overall result of a balance between distinct 5-HT systems in different brain areas. For example, microinjection of a $5-\mathrm{HT}_{2 \mathrm{C}}$ agonist generated opposite effects in the EPM depending on the brain areas targeted (Cornelio and Nunes-de-Souza, 2007; Nunes-de-Souza et al, 2008). This might explain the lack of changes in VMAT2 $2^{\text {sert-cre }}$ mice observed here with the EPM. The observed decrease in the exploratory behavior of VMAT2 $2^{\text {sert-cre }}$ mice, as in other hyposerotonergic models (Dringenberg et al, 1995; Hendricks et al, 2003), is also a confounding factor for the interpretation of EPM data. In contrast, consistent effects of 5-HT depletion have been noted in several models involving conflicts, in which reduced 5-HT tone was linked to decreased anxiety-like behaviors (Graeff, 2004). In the NSF, which involves a conflict between the drive to feed and risk assessment behaviors triggered by the unfamiliar environment, VMAT2 ${ }^{\text {sert-cre }}$ mice showed an anxiolytic-like behavioral profile. This agrees with the anxiolytic-like effect of PCPA-induced 5-HT depletion (Bechtholt et al, 2007) and with observations in other 5-HT depleted mutant mice (Dai et al, 2008; Kiyasova et al, 2011).

It is also interesting to note that VMAT2 ${ }^{\text {sert-cre }}$ mice spent more time struggling to escape than did control mice in the TST. This is coherent with observations in Tph1::Tph2 DKO mice which displayed increased struggling time in the forced swim test (FST) (Savelieva et al, 2008). The increase of struggling or escape-like behavior of VMAT2 $2^{\text {sert-cre }}$ mice in the TST might be mechanistically similar to the increase in ultrasound-induced flight also observed here with these mutants. Both of these effects can potentially be accounted for by a lack of inhibitory effect of 5-HT at the midbrain level (Kiser and Lebovitz, 1975). As far as we know, the present genetic invalidation study is the first that clearly indicates a tonic inhibitory role of endogenous 5-HT on the expression of active defense behaviors in reaction to fear stimuli. Previous pharmacological studies in rats showed that flight behaviors induced by an aversive ultrasound are decreased by the 5-HT agonist mCPP (Beckett et al, 1996). Furthermore, treatment with the MAOI phenelzine decreased flight behavior in the mouse defense battery test, and this was mostly apparent after chronic compared to acute treatment (Griebel et al, 1998). In our study, we have performed a long-term, rather than a short-term, MAOI treatment to optimally enhance 5-HT neurotransmission by desensitization of $5-\mathrm{HT}_{1 \mathrm{~A}}$ autoreceptors (Mongeau et al, 1997), which were found to be hypersensitive in $\mathrm{VMAT}^{\text {sert-cre }}$ mice (Figure 5).

In relation to depression, it is generally believed that a reduced brain 5-HT tone results in depressed-like behaviors in escape-related models of depression such as the TST or the FST. However, although 5-HT is necessary for the action of antidepressant drugs in these models, 5-HT depletion with PCPA generally fails to alter baseline immobility (Cryan et al, 2005; O'Leary et al, 2007). In contrast, depleting catecholamines in adult mice strongly increases baseline immobility in the TST (O'Leary et al, 2007). Constitutive knockdowns of VMAT2 (VMAT2+/-), which reduces the release of all monoamines, also results in an increased immobility in the FST and the TST (Fukui et al, 2007). However, the present observation that selective deletion of VMAT2 in serotonergic neurons decreased, rather than increased, immobility in the TST, together with previous observation (Savelieva et al, 2008) on Tph1::Tph2 DKO mice subjected to the FST, indicate that a depletion of 5-HT is insufficient to induce depression-like behaviors in such escape-related tests.

Furthermore, the antidepressant-like effect observed in the TST in VMAT2 $2^{\text {sert-cre }}$ mice might not be paradoxical considering that antidepressant drugs exert their effect in the TST after acute rather than chronic treatment (Cryan et al, 2005). It is important to emphasize here that although chronic treatments increase 5-HT neurotransmission, acute administrations do not (Mongeau et al, 1997). The transient surges of extracellular 5-HT levels, associated with acute antidepressant drugs, trigger strong inhibition of both 5-HT neuronal firing and release through negative autoreceptors feedback (Auerbach et al, 1995; Hajos et al, 1995; Hervas and Artigas, 1998; Hjorth and Auerbach, 1994).

\section{Conclusion and Perspectives}

Genetic invalidation of VMAT2 in 5-HT neurons provides an interesting model to test the function of endogenous 5-HT release in normally developed 5-HT raphe neurons. Using this model, we show that decrease in 5-HT results in an anxiolytic profile in a conflict test, contrasting with an increase in acute stress or innate fear stimulus-induced escape-like behaviors. Chronic treatment with a MAOI 
prevented the behavioral abnormality of VMAT2 $2^{\text {sert-cre }}$ mice in terms of defense to an innately aversive stimulus. Interestingly, flight reactions have often been used in validated models of panic disorders (Griebel et al, 1996) and chronic MAOIs are well known to be effective antipanic agents (Bakish et al, 1993). Incidentally, these data address new questions as to whether extrasynaptic or nonvesicular 5-HT release mechanisms might be involved in the therapeutic effects of this class of antidepressant drugs.

\section{ACKNOWLEDGEMENTS}

We thank Xiaoxi Zhuang and René Hen for the SERT-Cre mouse line. Funding for this project was from Agence Nationale de la Recherche (ANR-08-MNPS-032), the Région Île de France, DIM NeRF (for NNN), and from the European Commission (FP7-health-2007-A-201714). We thank all members of the DEVANX project for stimulating discussions and suggestions. NN-N was supported by Region Ile de France (NeRF). CBPM was funded by a studentship from the Ministère de l'Education Nationale et de la Recherche (France). SLD was supported by fellowships from IBRO and from Region Ile de France DIM STEM and SD by a LeFoulon-Delalande fellowship.

\section{DISCLOSURE}

The authors declare no conflict of interest.

\section{REFERENCES}

Adell A, Artigas F (1998). A microdialysis study of the in vivo release of $5-\mathrm{HT}$ in the median raphe nucleus of the rat. $\mathrm{Br} J$ Pharmacol 125: 1361-1367.

Alenina N, Kikic D, Todiras M, Mosienko V, Qadri F, Plehm R et al (2009). Growth retardation and altered autonomic control in mice lacking brain serotonin. Proc Natl Acad Sci USA 106: 10332-10337.

Alvarez C, Vitalis T, Fon EA, Hanoun N, Hamon M, Seif I et al (2002). Effects of genetic depletion of monoamines on somatosensory cortical development. Neuroscience 115: 753-764.

Attwell D, Barbour B, Szatkowski M (1993). Nonvesicular release of neurotransmitter. Neuron 11: 401-407.

Auerbach SB, Lundberg JF, Hjorth S (1995). Differential inhibition of serotonin release by $5-\mathrm{HT}$ and NA reuptake blockers after systemic administration. Neuropharmacology 34: 89-96.

Bakish D, Saxena BM, Bowen R, D’Souza J (1993). Reversible monoamine oxidase-A inhibitors in panic disorder. Clin Neuropharmacol 16(Suppl 2): S77-S82.

Bally-Cuif L, Wassef M (1994). Ectopic induction and reorganization of Wnt-1 expression in quail/chick chimeras. Development 120: 3379-3394.

Beaulieu JM, Zhang X, Rodriguiz RM, Sotnikova TD, Cools MJ, Wetsel WC et al (2008). Role of GSK3 beta in behavioral abnormalities induced by serotonin deficiency. Proc Natl Acad Sci USA 105: 1333-1338.

Bechtholt AJ, Hill TE, Lucki I (2007). Anxiolytic effect of serotonin depletion in the novelty-induced hypophagia test. Psychopharmacology (Berl) 190: 531-540.

Beckett SR, Aspley S, Graham M, Marsden CA (1996). Pharmacological manipulation of ultrasound induced defence behaviour in the rat. Psychopharmacology (Berl) 127: 384-390.
Berton O, Nestler EJ (2006). New approaches to antidepressant drug discovery: beyond monoamines. Nat Rev Neurosci 7: 137-151.

Bunin MA, Prioleau C, Mailman RB, Wightman RM (1998). Release and uptake rates of 5-hydroxytryptamine in the dorsal raphe and substantia nigra reticulata of the rat brain. J Neurochem 70: 1077-1087.

Bunin MA, Wightman RM (1999). Paracrine neurotransmission in the CNS: involvement of 5-HT. Trends Neurosci 22: 377-382.

Buu NT (1989). Modification of vesicular dopamine and norepinephrine by monoamine oxidase inhibitors. Biochem Pharmacol 38: $1685-1692$.

Cases O, Lebrand C, Giros B, Vitalis T, De Maeyer E, Caron MG et al (1998). Plasma membrane transporters of serotonin, dopamine, and norepinephrine mediate serotonin accumulation in atypical locations in the developing brain of monoamine oxidase A knock-outs. J Neurosci 18: 6914-6927.

Christiansen L, Tan Q, Iachina M, Bathum L, Kruse TA, McGue M et al (2007). Candidate gene polymorphisms in the serotonergic pathway: influence on depression symptomatology in an elderly population. Biol Psychiatry 61: 223-230.

Cornelio AM, Nunes-de-Souza RL (2007). Anxiogenic-like effects of mCPP microinfusions into the amygdala (but not dorsal or ventral hippocampus) in mice exposed to elevated plus-maze. Behav Brain Res 178: 82-89.

Cote F, Thevenot E, Fligny C, Fromes Y, Darmon M, Ripoche MA et al (2003). Disruption of the nonneuronal tphl gene demonstrates the importance of peripheral serotonin in cardiac function. Proc Natl Acad Sci USA 100: 13525-13530.

Cryan JF, Mombereau C, Vassout A (2005). The tail suspension test as a model for assessing antidepressant activity: review of pharmacological and genetic studies in mice. Neurosci Biobehav Rev 29: 571-625.

Dai JX, Han HL, Tian M, Cao J, Xiu JB, Song NN et al (2008). Enhanced contextual fear memory in central serotonin-deficient mice. Proc Natl Acad Sci USA 105: 11981-11986.

Dringenberg HC, Hargreaves EL, Baker GB, Cooley RK, Vanderwolf CH (1995). p-Chlorophenylalanine-induced serotonin depletion: reduction in exploratory locomotion but no obvious sensory-motor deficits. Behav Brain Res 68: 229-237.

Erickson JD, Eiden LE (1993). Functional identification and molecular cloning of a human brain vesicle monoamine transporter. J Neurochem 61: 2314-2317.

Erickson JD, Schafer MK, Bonner TI, Eiden LE, Weihe E (1996). Distinct pharmacological properties and distribution in neurons and endocrine cells of two isoforms of the human vesicular monoamine transporter. Proc Natl Acad Sci USA 93: 5166-5171.

Evans SM, Collard KJ (1988). The mechanism by which monoamine oxidase inhibitors give rise to a non-calcium-dependent component in the depolarization-induced release of 5-HT from rat brain synaptosomes. $\mathrm{Br} J$ Pharmacol 95: 950-956.

Fabre V, Beaufour C, Evrard A, Rioux A, Hanoun N, Lesch KP et al (2000). Altered expression and functions of serotonin 5-HT1A and 5-HT1B receptors in knock-out mice lacking the 5-HT transporter. Eur J Neurosci 12: 2299-2310.

Fon EA, Pothos EN, Sun BC, Killeen N, Sulzer D, Edwards RH (1997). Vesicular transport regulates monoamine storage and release but is not essential for amphetamine action. Neuron 19: 1271-1283.

Freis ED (1954). Mental depression in hypertensive patients treated for long periods with large doses of reserpine. $N$ Engl J Med 251: 1006-1008.

Fukui M, Rodriguiz RM, Zhou J, Jiang SX, Phillips LE, Caron MG et al (2007). Vmat2 heterozygous mutant mice display a depressive-like phenotype. J Neurosci 27: 10520-10529.

Gaspar P, Duyckaerts C, Alvarez C, Javoy-Agid F, Berger B (1991). Alterations of dopaminergic and noradrenergic innervations in motor cortex in Parkinson's disease. Ann Neurol 30: 365-374. 
Graeff FG (2004). Serotonin, the periaqueductal gray and panic. Neurosci Biobehav Rev 28: 239-259.

Gray EG, Whittaker VP (1962). The isolation of nerve endings from brain: an electron-microscopic study of cell fragments derived by homogenization and centrifugation. J Anat 96: 79-88.

Gray JA, McNaughton N (2000). The Neuropsychology of Anxiety. Oxford Medical Publications: Oxford.

Griebel G (1995). 5-Hydroxytryptamine-interacting drugs in animal models of anxiety disorders: more than 30 years of research. Pharmacol Ther 65: 319-395.

Griebel G, Blanchard DC, Blanchard RJ (1996). Predator-elicited flight responses in Swiss-Webster mice: an experimental model of panic attacks. Prog Neuropsychopharmacol Biol Psychiatry 20: 185-205.

Griebel G, Curet O, Perrault G, Sanger DJ (1998). Behavioral effects of phenelzine in an experimental model for screening anxiolytic and anti-panic drugs: correlation with changes in monoamineoxidase activity and monoamine levels. Neuropharmacology 37: 927-935.

Gutierrez B, Rosa A, Papiol S, Arrufat FJ, Catalan R, Salgado P et al (2007). Identification of two risk haplotypes for schizophrenia and bipolar disorder in the synaptic vesicle monoamine transporter gene (SVMT). Am J Med Genet B Neuropsychiatr Genet 144B: 502-507.

Gutknecht L, Waider J, Kraft S, Kriegebaum C, Holtmann B, Reif A et al (2008). Deficiency of brain 5-HT synthesis but serotonergic neuron formation in Tph2 knockout mice. J Neural Transm 115: $1127-1132$.

Hajos M, Gartside SE, Sharp T (1995). Inhibition of median and dorsal raphe neurones following administration of the selective serotonin reuptake inhibitor paroxetine. Naunyn Schmiedebergs Arch Pharmacol 351: 624-629.

Heisler LK, Zhou L, Bajwa P, Hsu J, Tecott LH (2007). Serotonin 5-HT(2C) receptors regulate anxiety-like behavior. Genes Brain Behav 6: 491-496.

Hekmatpanah CR, Peroutka SJ (1990). 5-Hydroxytryptamine uptake blockers attenuate the 5-hydroxytryptamine-releasing effect of 3,4-methylenedioxymethamphetamine and related agents. Eur J Pharmacol 177: 95-98.

Hendricks TJ, Fyodorov DV, Wegman LJ, Lelutiu NB, Pehek EA, Yamamoto B et al (2003). Pet-1 ETS gene plays a critical role in 5 -HT neuron development and is required for normal anxietylike and aggressive behavior. Neuron 37: 233-247.

Henry JP, Sagne C, Bedet C, Gasnier B (1998). The vesicular monoamine transporter: from chromaffin granule to brain. Neurochem Int 32: 227-246.

Hervas I, Artigas F (1998). Effect of fluoxetine on extracellular 5 -hydroxytryptamine in rat brain. Role of 5-HT autoreceptors. Eur J Pharmacol 358: 9-18.

Hjorth S, Auerbach SB (1994). Further evidence for the importance of 5-HT1A autoreceptors in the action of selective serotonin reuptake inhibitors. Eur J Pharmacol 260: 251-255.

Holtje M, Winter S, Walther D, Pahner I, Hortnagl H, Ottersen OP et al (2003). The vesicular monoamine content regulates VMAT2 activity through Galphaq in mouse platelets. Evidence for autoregulation of vesicular transmitter uptake. $J$ Biol Chem 278: $15850-15858$.

Kiser RS, Lebovitz RM (1975). Monoaminergic mechanisms in aversive brain stimulation. Physiol Behav 15: 47-53.

Kiyasova V, Fernandez SP, Laine J, Stankovski L, Muzerelle A, Doly $S$ et al (2011). A genetically defined morphologically and functionally unique subset of 5-HT neurons in the mouse raphe nuclei. J Neurosci 31: 2756-2768.

Lucki I (1998). The spectrum of behaviors influenced by serotonin. Biol Psychiatry 44: 151-162.

Mannoury La Cour C, El Mestikawy S, Hanoun N, Hamon M, Lanfumey L (2006). Regional differences in the coupling of 5-hydroxytryptamine-1A receptors to $\mathrm{G}$ proteins in the rat brain. Mol Pharmacol 70: 1013-1021.
McCreary AC, McBlane JW, Spooner HA, Handley SL (1996). 5-HT systems and anxiety: multiple mechanisms in the elevated X-maze. Pol J Pharmacol 48: 1-12.

McKenna DJ, Guan XM, Shulgin AT (1991). 3,4-Methylenedioxyamphetamine (MDA) analogues exhibit differential effects on synaptosomal release of $3 \mathrm{H}$-dopamine and $3 \mathrm{H}-5$-hydroxytryptamine. Pharmacol Biochem Behav 38: 505-512.

Mongeau R, Blier P, de Montigny C (1997). The serotonergic and noradrenergic systems of the hippocampus: their interactions and the effects of antidepressant treatments. Brain Res Brain Res Rev 23: 145-195.

Mongeau R, de Montigny C, Blier P (1994). Activation of 5-HT3 receptors enhances the electrically evoked release of $[3 \mathrm{H}]$ noradrenaline in rat brain limbic structures. Eur J Pharmacol 256: 269-279.

Mongeau R, Martin CB, Chevarin C, Maldonado R, Hamon M, Robledo $\mathrm{P}$ et al (2010). 5-HT(2c) receptor activation prevents stress-induced enhancement of brain 5-HT turnover and extracellular levels in the mouse brain: modulation by chronic paroxetine treatment. J Neurochem 115: 438-449.

Mongeau R, Miller GA, Chiang E, Anderson DJ (2003). Neural correlates of competing fear behaviors evoked by an innately aversive stimulus. J Neurosci 23: 3855-3868.

Morilak DA, Frazer A (2004). Antidepressants and brain monoaminergic systems: a dimensional approach to understanding their behavioural effects in depression and anxiety disorders. Int J Neuropsychopharmacol 7: 193-218.

Narboux-Nême N, Mongeau R, Sagne C, Angenard G, Hamon M, Martres MP et al (2009). Severe serotonin depletion, growth and behavioral abnormalities in conditional vesicular monoamine transporter 2 knockout mouse. Soc Neurosci Abstract 90.9.

Narboux-Neme N, Pavone LM, Avallone L, Zhuang X, Gaspar P (2008). Serotonin transporter transgenic (SERTcre) mouse line reveals developmental targets of serotonin specific reuptake inhibitors (SSRIs). Neuropharmacology 55: 994-1005.

Njus D, Kelley PM, Harnadek GJ (1986). Bioenergetics of secretory vesicles. Biochim Biophys Acta 853: 237-265.

Nunes-de-Souza V, Nunes-de-Souza RL, Rodgers RJ, Canto-deSouza A (2008). 5-HT2 receptor activation in the midbrain periaqueductal grey (PAG) reduces anxiety-like behaviour in mice. Behav Brain Res 187: 72-79.

O'Connor JJ, Kruk ZL (1991). Fast cyclic voltammetry can be used to measure stimulated endogenous 5-hydroxytryptamine release in untreated rat brain slices. J Neurosci Methods 38: 25-33.

O'Leary OF, Bechtholt AJ, Crowley JJ, Hill TE, Page ME, Lucki I (2007). Depletion of serotonin and catecholamines block the acute behavioral response to different classes of antidepressant drugs in the mouse tail suspension test. Psychopharmacology (Berl) 192: 357-371.

Renoir T, Paizanis E, El Yacoubi M, Saurini F, Hanoun N, Melfort $M$ et al (2008). Differential long-term effects of MDMA on the serotoninergic system and hippocampal cell proliferation in 5-HTT knock-out $v s$ wild-type mice. Int J Neuropsychopharmacol 11: 1149-1162.

Savelieva KV, Zhao S, Pogorelov VM, Rajan I, Yang Q, Cullinan E et al (2008). Genetic disruption of both tryptophan hydroxylase genes dramatically reduces serotonin and affects behavior in models sensitive to antidepressants. PLoS One 3: e3301.

Shih JC, Grimsby J, Chen K (1997). Molecular biology of monoamines oxidases $\mathrm{A}$ and $\mathrm{B}$ : their role in the degradation of serotonin. In: Handbook of Experimental Pharmacology. Springer-Verlag: Berlin. pp 655-670.

Trowbridge S, Narboux-Neme N, Gaspar P (2010). Genetic models of serotonin (5-HT) depletion: what do they tell us about the developmental role of 5-HT? Anat Rec (Hoboken) (ahead of print).

Vitalis T, Fouquet C, Alvarez C, Seif I, Price D, Gaspar P et al (2002). Developmental expression of monoamine oxidases A and $B$ in the central and peripheral nervous systems of the mouse. J Comp Neurol 442: 331-347. 
VMAT2 conditional deletion N Narboux-Nême et al

Wang YM, Gainetdinov RR, Fumagalli F, Xu F, Jones SR, Bock CB et al (1997). Knockout of the vesicular monoamine transporter 2 gene results in neonatal death and supersensitivity to cocaine and amphetamine. Neuron 19: 1285-1296.

Weisstaub NV, Zhou M, Lira A, Lambe E, Gonzalez-Maeso J, Hornung JP et al (2006). Cortical 5-HT2A receptor signaling modulates anxiety-like behaviors in mice. Science 313: 536-540.

Wu Y, Wang W, Diez-Sampedro A, Richerson GB (2007). Nonvesicular inhibitory neurotransmission via reversal of the GABA transporter GAT-1. Neuron 56: 851-865.
Zhao S, Edwards J, Carroll J, Wiedholz L, Millstein RA, Jaing C et al (2006). Insertion mutation at the C-terminus of the serotonin transporter disrupts brain serotonin function and emotion-related behaviors in mice. Neuroscience 140: 321-334.

Zhou FM, Liang Y, Salas R, Zhang L, De Biasi M, Dani JA (2005). Corelease of dopamine and serotonin from striatal dopamine terminals. Neuron 46: 65-74.

Zhuang X, Masson J, Gingrich JA, Rayport S, Hen R (2005). Targeted gene expression in dopamine and serotonin neurons of the mouse brain. J Neurosci Methods 143: 27-32.

Supplementary Information accompanies the paper on the Neuropsychopharmacology website (http://www.nature.com/npp) 